\title{
MEMAKNAI KERAGAMAN: The Others dalam Konstruksi Sosial Para Elit Kelompok-kelompok Keagamaan di Kota Mataram
}

\author{
Fawaizul Umam \\ Institut Agama Islam Negeri (IAIN) Mataram \\ e-mail: fawaizu@yahoo.com
}

\begin{abstract}
Based on the urgency of the involvement of the groups' views on the others in any peace initiation, this study attempted (1) to investigate how the leaders of religious groups in Mataram socially constructed the others and (2) to determine the typology of their social constructions by relying on three main paradigms of religiosity (exclusivism, inclusivism, pluralism). The leaders of religious groups were chosen as a major subject because they had contributed significantly to the social dynamics of the Muslims in this city; as religious elites (ulama), they were not only cultural brokers, but also active creators of social change. To analyze their social constructions on the others, this research used the Berger's social constructionism theory. Their social constructions excavated from purposively selected informants, namely the formal or informal elites of religious groups like the Ahmadiyya, Salafists, Tablighi Jamaat, Shiite, and the traditionalist (Nahdlatul Wathan) and modernist (Muhammadiyah) Islamic groups. It was concluded that their social constructions actually emerged through three moments of dialectic which formed the subjective and objective realities on the others. Through those social constructions, they defined the others. All of their social constructions typologically tended to be exclusive, in certain limits also inclusive, and pluralistic tendencies tended to be absent. Based on the typefication, this study proposed a number of ideal solutions for creating the coexistence of Islamic religious groups in Mataram
\end{abstract}

\begin{abstract}
Abstrak: Bertolak dari urgensi pelibatan pandangan masing-masing kelompok tentang the others dalam setiap inisiasi perdamaian, studi ini mengkaji (1) konstruksi sosial para elit kelompok-kelompok keagamaan di Kota Mataram tentang the others sekaligus menentukan (2) tipologinya berdasar tiga model utama keberagamaan, yakni eksklusivisme, inklusivisme, dan pluralisme. Para elit dipilih sebagai subjek karena mereka berperan signifikan dalam kelompok masing-masing. Dalam dinamika sosial masyarakat Muslim Kota Mataram, mereka kurang-lebih adalah ulama yang berperan sebagai "makelar budaya" sekaligus kreator aktif perubahan sosial. Untuk memahami konstruksi sosial para elit tentang the others, studi ini menerapkan teori konstruksi sosial Berger. Data utama digali dari para informan yang dipilih secara purposif, yakni mereka yang secara formal maupun informal memimpin kelompok-kelompok keagamaan Islam seperti Ahmadiyah, Salafi, Jama'ah Tabligh, Syi'ah, dan juga kelompok tradisionalis (Nahdlatul Wathan) dan modernis (Muhammadiyah). Hasil kajian menunjukkan bahwa konstruksi sosial mereka muncul lewat tiga momen dialektik yang membentuk realitas subjektif sekaligus objektif tentang the others. Hal itu menentukan cara mereka selaku elit kelompok dalam
\end{abstract}


memaknai dan menyikapi the others. Tipefikasinya menunjukkan, penyikapan mereka tentang the others cenderung eksklusif, dalam batas-batas tertentu inklusif, sementara tendensi pluralistik cenderung absen. Berdasar itu solusi berupa format ideal pengelolaan keragaman bagi penciptaan koeksistensi antarkelompok keagamaan di Kota Mataram diajukan.

Keywords: kelompok keagamaan; elit; konstruksi sosial; model keberagamaan; tipologi

\section{A. Pendahuluan}

Eskalasi konflik-konflik keagamaan di berbagai daerah, termasuk di Kota Mataram, ditentukan antara lain oleh preferensi subjektif keberagamaan para penganut agama, yakni identifikasi diri mereka yang menjadikan mereka (merasa) berbeda dengan individu lain yang beragama atau berkeyakinan beda. ${ }^{1}$ Sayangnya, gairah identifikasi diri itu cenderung absen sebagai salah satu pertimbangan dalam setiap ajuan resolusi atas konflik. Setiap inisiasi penciptaan kerukunan umumnya tidak bertolak dari pandangan setiap kelompok tentang "yang lain" yang dengannya mereka mengidentifikasi diri dan menjadikan mereka merasa berbeda dengan "yang lain" itu. Akibatnya, berbagai inisiasi perdamaian cenderung melahirkan kerukunan semu (pseudo-harmony) sehingga kerap tidak langgeng dalam mengkondisikan relasi produktif antarkelompok keagamaan.

Itulah mengapa penting menimbang bagaimana masing-masing kelompok keagamaan mengkonstruksi kelompok lain (the others) yang berbeda keyakinan atau anutan agama sebagai dasar pertimbangan untuk mengelola perbedaan sekaligus menciptakan kebersamaan produktif antarkelompok keagamaan. Untuk konteks Kota Mataram yang berpenduduk mayoritas Muslim dan potensi konflik antarkelompok keagamaannya terus membesar, hal itu penting, terutama sebagai ancangan awal menyikapi keragaman sekaligus merintis upaya membangun format kehidupan keagamaan inklusif di kalangan umat Islam.

Selanjutnya, bagaimana konstruksi sosial para elit kelompok keagamaan Muslim di Kota Mataram tentang the others penting dipahami (verstehen) karena dari merekalah masing-masing kelompok keagamaan memahami the others sekaligus memaknai keragaman. Selanjutnya, terhadap segenap konstruksi sosial mereka itu dilakukan tipefikasi, suatu penentuan tipologi pengetahuan 49.

${ }^{1}$ Samuel P. Huntington, “The Clash of Civilization?” dalam Foreign Affairs (Summer, 1993), h. 22- 
atau kesadaran keagamaan. Hal ini dimaksudkan untuk memperoleh gambaran tentang berbagai potensi latent yang secara epistemologis dapat menghambat dan/atau melempangkan jalan bagi penciptaan model kehidupan keagamaan inklusif. Seluruh gambaran lalu dimanfaatkan sebagai dasar membangun format ideal pengelolaan kehidupan keagamaan umat Islam yang inklusif di kota ini.

Secara teoretis, hasil studi ini berguna terutama dalam kerangka pengayaan teori seputar perbandingan agama, hubungan dan dialog antaragama, pola dakwah, pluralisme agama, dan hak asasi manusia (HAM), khususnya hak kebebasan beragama dan berkeyakinan (freedom of religion or belief). Sementara, secara praktis, ia dapat menjadi pertimbangan bagi para penentu kebijakan dalam merumuskan kebijakan-kebijakan publik di bidang sosial-keagamaan; minimal, sebagai acuan penyusunan suatu early warning system ${ }^{2}$ demi mengantisipasi eksplosi konflik-konflik keagamaan di Kota Mataram. Selain itu, bagi lembaga-lembaga pendidikan keagamaan, ia juga berguna sebagai reasoning untuk meredesain kurikulum ke arah yang lebih apresiatif terhadap pluralitas agama dan heterogenitas pemahaman keagamaan. Selebihnya, ia bermanfaat pula sebagai bahan informatif bagi institusi-institusi "semi-negara" seperti Forum Kerukunan Umat Beragama (FKUB) dan Majelis Ulama Indonesia (MUI), dan juga lembaga-lembaga swadaya masyarakat (LSM) yang menaruh concern di isu-isu dialog dan mediasi konflik untuk, misalnya, menyusun desain aksi dalam mengadvokasi dinamika hubungan antarkelompok keagamaan.

\section{B. Metode Kajian}

Secara keseluruhan, artikel ini merupakan hasil penelitian yang penulis lakukan dalam rentang hampir tiga tahun, yakni dari 2013 akhir hingga awal 2016. Locus penelitiannya adalah Kota Mataram. Ibukota Provinsi Nusa Tenggara Barat (NTB) ini dipilih, terutama karena —-berdasar temuan penelitian pada tahun pertama hingga kedua - konflik-konflik antarumat beragama maupun antarkelompok sesama Muslim, baik yang aktual maupun yang masih potensial, begitu tinggi. Menimbang itu, pada setahun terakhir (2015-2016), penelitian beralih fokus pada penelusuran konstruksi sosial para elit kelompok keagamaan Muslim, baik yang langsung terlibat konflik maupun tidak; di-

2Tentang signifikansi sosial sistem siaga dini ini lihat utuh Jajat Burhanudin dan Arief Subhan (eds.), Sistem Siaga Dini terhadap Kerusuhan Sosial (Jakarta: Balitbang Agama Depag RI dan PPIM, 2000).

JURNAL THEOLOGIA — Volume 27, Nomor 2, Desember 2016 
maksudkan sebagai bentuk pendalaman di mana pemahaman para elit diandaikan bersumbangsih penting pada eskalasi konflik. Fokus inilah yang diketengahkan dalam artikel ini.

Seluruh data terkait yang digali lewat observasi, telusur dokumen, dan wawancara mendalam dimanfaatkan sebagai basis tolak mengkaji bagaimana masing-masing kelompok keagamaan di Kota Mataram, yang dalam hal ini direpresentasikan para elitnya, secara sosial mengkonstruksi kelompok lain (the others) yang berbeda keyakinan. Pemilihan para elit kelompok sebagai subjek bertolak dari suatu teori lazim bahwa sebagai elit kelompok, mereka berperan signifikan bagi kelompoknya. ${ }^{3}$ Para elit itu kurang-lebih adalah tokoh agama (ulama) yang tidak hanya memainkan peran sebagai "makelar budaya" (cultural broker),4 tetapi juga sebagai kreator aktif perubahan sosial..$^{5}$ Jadi, wajar jika masyarakat atau anggota kelompok keagamaan terkait seringkali meng-copy paste keberagamaan elitnya, termasuk dalam memandang dan menyikapi apa yang disebut the others.

Konsep the other (sang liyan) atau the others (paraliyan) dalam studi ini meminjam pemaknaan galib dalam postcolonial studies. Dalam diskursus poskolonial, pandangan akan "ke-yang-lain-an" (otherness) bertumpu pada egosentrisme yang memandang diri lebih unggul dibanding "yang lain" (the others). ${ }^{6}$ Pandangan ini tidak hanya menjadi dasar dalam memandang "yang lain", tetapi juga mengkonstruk seluruh pengetahuan tentang "yang lain" sekaligus memperlakukannya secara berbeda dengan diri. Diri pun mengambil jarak sebagai subjek dengan mengobjekkan "yang lain" sehingga berkonsekuensi pada munculnya separasi, oposisi, dan alienasi. ${ }^{7}$

Dalam konteks hubungan antarkelompok keagamaan, relasi kuasa dibangun di atas ideologi pengetahuan keagamaan tertentu dengan menempatkan

${ }^{3}$ Mark N. Hagopian, Regimes, Movement, and Ideology (New York: Longman, 1978), h. 223-249.

${ }^{4}$ Clifford Geertz, "The Javanese Kijaji: The Changing Role of a Cultural Broker," dalam Comparative Studies on Society and History, II/2 (January, 1960), h. 228-249.

${ }^{5}$ Hiroko Horikoshi Roe, Kyai dan Perubahan Sosial, terj. Umar Basalim dan Andy Muarly Sunrawa (Jakarta: P3M, 1987), h. 242.

${ }^{6}$ Makarand Paranjape, "The Third Eye and Two Ways of (Un)knowing: Gnosis, Alternative Modernities, and Postcolonial Futures", dalam Andrew B. Irvine and Purushottama Bilimoria (eds.), Postcolonial Philosophy of Religion (tt:: Springer, 2009), h. 55-67.

${ }^{7}$ Ibid. 
pengetahuan keagamaan the others sebagai entitas yang harus ditundukkan.8 Keyakinan religius diri didaku sebagai yang paling benar. Tidak ada pilihan bagi the others kecuali menyesuaikan dengan konstruksi keyakinan religius diri atau jika tidak dengan segera dilekati stigma "sesat-menyimpang". Inilah yang pada gilirannya melahirkan tendensi superioritas diri di hadapan the others.

Untuk memahami makna di balik tindakan dan bagaimana para elit kelompok mengkonstruksi the others dalam konteks hubungan antarkelompok keagamaan, studi ini secara khusus meminjam teori konstruksi sosial (social constructionism theory) ajuan Peter L. Berger. ${ }^{9}$ Selanjutnya, terhadap seluruh konstruksi sosial mereka diterapkan proses tipefikasi yang kerangka tipologinya bersandar pada tiga model utama keberagamaan, yakni eksklusivisme, inklusivisme, dan pluralisme. Hasilnya lalu dijadikan titik pijak untuk merumuskan pola ideal pengelolaan kehidupan keberagamaan umat Islam di Kota Mataram.

\section{Hasil dan Pembahasan}

\section{Arena Kontestasi}

Sejumlah konflik di Tanah Air menunjukkan betapa tendensi agama tidak dapat diabaikan signifikansinya dalam mempengaruhi besaran konflik. ${ }^{10}$ Demikian pula halnya di Kota Mataram. Potensi benturan antarumat selalu merupakan ancaman latent. Preseden historisnya pun bukan tidak pernah ada. ${ }^{11}$ Tunjuk misal, pertikaian antara kaum Muslim (etnis Samawa, sebagian Sasak) dan Hindu (etnis Bali) tahun 1980 yang berlanjut menjadi perselisihan historis yang cenderung berulang di kampung Taliwang Cakranegara dan sekitarnya, pertikaian antarkampung Karang Tapen (Muslim) dengan Karang

\footnotetext{
${ }^{8}$ Donna Landry dan Gerald MacLean (eds.), The Spivak Reader: Selected Works of Gayatri Chakravorty Spivak (New York: Routledge, 1996), h. 141-174.

${ }^{9}$ Peter L. Berger, Langit Suci: Agama sebagai Realitas Sosial, terj. Hartono (Jakarta: LP3ES, 1991), h. 5, 32-5; Peter L Berger dan Thomas Luckmann, Tafsir Sosial atas Kenyataan: Risalah tentang Sosiologi Pengetahuan (Jakarta: LP3ES, 1991), h. 28-65; Gary Dorrien, "Berger: Theology and Sociology", dalam Peter Berger and the Study of Religion, ed. Linda Woodhead, etal. (London: Routledge, 2001), h. 26-39; dan David G. Horrell, "Berger and New Testament Studies", dalam Linda Woodhead, etal,, Peter Berger and the Study of Religion (London: Routledge, 2001), h. 142-153.

${ }^{10}$ Lihat selengkapnya Ihsan Ali-Fauzi, Rudy Harisyah Alam, dan Samsu Rizal Panggabean, "Polapola Konflik Keagamaan di Indonesia (1990-2008)", Laporan Penelitian--Paramadina-MPRK UGM-The Asia Foundation (Jakarta, 2009); Ismail Hasani, ed. Submissive to Mass Judgment: State's Justification in Prosecuting Freedom of Religion and Belief (Jakarta: SETARA Institute, 2007).

${ }^{11}$ Asnawi, "Konflik dan Karakteristiknya," Makalah (tidak diterbitkan), (Mataram: Mediation Centre IAIN Mataram, 2004), h. 1-8.
} 
Jasi dan Karang Ledek (Hindu) pada tahun 1996, 2003, dan 2004, dan antara warga Nyangget dan Saksari pada tahun 2000, 2002, dan 2008, serta pertikaian antarwarga di Gubug Mamben Sekarbela Kota Mataram pada 2012. Dari sekian kasus, rusuh massif bernuansa agama yang berujung pembakaran sejumlah rumah ibadah dan eksodus etnis Tionghoa pada 17 Januari 2000 menjadi tahap puncak dari sejarah kekerasan kontemporer di kota ini. ${ }^{12}$

Sementara itu, konflik di internal komunitas seagama juga tidak kalah marak. Di internal Muslim, sejumlah kasus kekerasan yang menimpa Jemaat Ahmadiyah, kaum Muslim Salafi, dan komunitas Syi'ah adalah deretan contoh aktual konflik di Lombok umumnya dan Kota Mataram khususnya. Sekedar menunjuk, kekerasan beruntun berupa perusakan rumah teralami sejumlah warga Muslim Salafi di Sesela Batu Layar dan Sekotong serta Blongas Gerung pada 2009 dan juga pembubaran paksa peringatan Asyura kaum Syi'i di Ampenan Mataram pada 13 Januari 2008.13 Di Lombok Timur, pemukiman warga Ahmadiyah diserang dan dibakar massa pada 10-13 September 2002. Hal yang sama juga terjadi di Praya Lombok Tengah pada 17 Maret 2006. Sebulan sebelumnya, 4 Februari 2006, tragedi serupa menimpa mereka di Ketapang Lingsar; para koraban terlunta di pengungsian Asrama Transito Kota Mataram hingga kini. ${ }^{14}$

Sejauh menyangkut dinamika hubungan antarkelompok keagamaan sesama Muslim, potensi benturan di Kota Mataram tampaknya cenderung selalu besar. Potensi laten konfliktual setidaknya dapat dipindai dari konfigurasi keagamaan masyarakat di kota ini yang demikian heterogen. Heterogenitasnya dapat dibaca dari dua indikator utama pluralitas keagamaan, yakni indikator eksternal dan internal agama. Indikator eksternal menunjukkan heterogenitas itu berhulu pada pluralitas agama, sementara indikator internal menampak lewat keragaman kelompok keyakinan di intern agama-agama itu sendiri, tak terkecuali di lingkup umat Islam yang notabene merupakan komunitas keagamaan mayoritas di kota ini.

${ }^{12}$ Ahmad Amir Aziz, dkk. "Tragedi 171 Mataram: Wujud Ketidakberesan Hubungan Antarumat Beragama?” Jurnal Ulumuna STAIN Mataram Vol. VIII Edisi 14 No. 2 (Juli-Desember, 2004): 300-17.

${ }^{13}$ Lihat "Lampu Merah Kebebasan Beragama: Laporan Kebebasan Beragama dan Toleransi di Indonesia The WAHID Institute 2011", dalam http://www.wahidinstitute.org/Dokumen/Detail/?id $=184 / \mathrm{hl}=$ id/Laporan_Kebebasan_Beragama_2011_The_Wahid_Institute (3 Maret 2016); dan M. Sai, dkk., "Gerakan Dakwah Salafiyah (Konflik Ideologis dan Sosial di Lombok Barat)," Laporan Penelitian-Lemlit IAIN Mataram (Mataram, 2007).

${ }^{14}$ Fawaizul Umam, “Menolak Kekerasan, Menenggang Keragaman: Refleksi atas Kasus Kekerasan terhadap Ahmadiyah”, Jurnal Tasâmuh FD IAIN Mataram Vol. 4 No. 1 (Desember, 2006): 25-38. 
Terdapat sejumlah kelompok keyakinan Muslim di Kota Mataram yangdari sudut tilikan atas varian keyakinan, orientasi, ideologi, dan paradigma pemikiran keagamaannya — satu sama lain berbeda. Dari sekian kelompok, ada beberapa yang terbilang menonjol. Enam kelompok di antaranya menjadi subjek utama studi ini, yakni Ahmadiyah, Salafi, Jamaah Tabligh, Syiah, dan kelompok-kelompok keislaman modernis (Muhammadiyah) dan tradisionalis yang dalam studi ini direpresentasikan Nahdlatul Wathan (NW).

Dinamika kehidupan keagamaan di Kota Mataram terus berlangsung dinamis, terutama karena masing-masing kelompok keagamaan senantiasa memiliki hasrat dakwah. Aktivitas dakwah kurang-lebih menjadi ajang peneguhan eksistensi diri mereka di tengah umat. Setiap kelompok membangun modus eksistensial diri di ruang publik (public sphere) dan karena itu menjadikan kota ini tak ubahnya arena kontestasi. Melalui dakwah, mereka saling mengukuhkan eksistensi diri sembari, langsung maupun tidak, saling mendelegitimasi eksistensi satu sama lain.

Merujuk hasil wawancara dan observasi, aktivitas dakwah terutama berlangsung di intern kelompok keagamaan masing-masing. Aktivitas dakwah yang lebih terbuka tentu saja dilangsungkan oleh kelompok keislaman mayoritas, NW dan Muhammadiyah. Merekalah yang berkelebat di ruang publik dengan memanfaatkan semua media komunikasi. Sementara kelompok minoritas, selain memanfaatkan secara sangat terbatas media publik itu, aktivitas dakwah mereka cenderung berkutat di intern jamaah masing-masing dan jikapun keluar dilakukan lewat penyebaran buletin terbitan sendiri dengan peredaran terbatas.

\section{Konstruksi Sosial tentang The Others}

Berdasar pengenaan teori konstruksi sosial sebagai perspektif,, ${ }^{15}$ para informan yang notabene elit kelompok selalu melangsungkan interaksi simultan dengan realitas sosial-keagamaan Kota Mataram. Mereka hidup dalam realitas

\footnotetext{
${ }^{15}$ Konstruksi sosial dibangun melalui dua cara. Pertama, melalui proses mendefinisikan "realitas" dan "pengetahuan". Realitas sosial adalah sesuatu yang manifest dalam pergaulan sosial lewat komunikasi dan kerja sama melalui organisasi-organisasi sosial; ia terjumpai dalam pengalaman intersubjektif. Pengetahuan tentangnya mencakup ranah kognitif, psikomotorik, emosional, dan intuitif dari segenap aspek kehidupan masyarakat. Kedua, untuk meneliti sesuatu yang intersubjektif itu, realitas sosial harus dilihat sebagai berwajah ganda di mana dimensi objektivitas dan subjektivitas berbaur. Kedua dimensi merupakan entitas integral dalam setiap realitas sosial sehingga realitas harus dimaknai sebagai objektif dan subjektif sekaligus. Lihat Berger dan Luckmann, Tafsir Sosial, h. 28-65; Horrell, "Berger," h. 142-53.
} 
ganda, yakni realitas objektif yang mereka konstruksi melalui momen eksternalisasi dan objektivasi sekaligus subjektif yang mereka konstruksi lewat momen internalisasi. Di titik inilah konstruksi sosial mereka tentang the others tampil sebagai "rezim pengetahuan" yang turut andil menentukan dinamika keagamaan.

Dengan perpsektif teori itu pula, studi ini menjumpai realitas bagaimana sistem keyakinan dan bagan pengetahuan tentang the others dikonstruksi para informan. Seluruh konstruksi sosial mereka merupakan realitas sosial yang tercipta melalui tiga momen dialektik, yakni eksternalisasi, objektivasi, dan internalisasi. Pada momen eksternalisasi, pikiran ( $m i n d$ ) dan tindakan (act) para informan menegaskan betapa setiap fenomena dan tindakan sosial selalu memiliki basis historis dan dasar normatifnya sendiri, termasuk konstruksi sosial mereka tentang the others. Mereka cenderung selalu melakukan penyesuaian dengan teks-teks suci (al-Qur'an dan al-Hadis) seraya memegang interpretasi ulama terdahulu ke mana genealogi pengetahuan mereka tentang the others dapat dilacak. Berdasar itu, para informan lalu melangsungkan adaptasi diri di tengah dinamika sosial-keagamaan di Kota Mataram.

Kecenderungan tersebut terjumpai dalam gugus pengetahuan informan, misalnya, saat memaknai keragaman keyakinan dan kelompok di intern umat Islam. Hampir semua informan menyebut realitas plural itu sebagai sunnatullāh yang memiliki sandaran normatif dan basis historis. Untuk legitimasi, mereka mendasarkan diri pada sejumlah ayat al-Qur'an tentang kesengajaan Allah swt menciptakan pluralitas semata-mata sebagai ujian agar manusia berlomba berbuat kebajikan, ${ }^{16}$ juga hadits masyhur yang menyebutkan Rasul Muhammad saw telah meramalkan umatnya di akhir zaman bakal terpecah ke dalam banyak golongan. Mereka juga menunjuk fakta historis betapa perbedaan dan keragaman merupakan hal lazim sepanjang sejarah umat Islam. Dalam pada itu mereka merujuk pada tokoh-tokoh panutan kelompok mereka sendiri. Informan Salafi, misalnya, cenderung selalu merujuk pada interpretasi keagamaan Syekh al-Albany, Bin Baz, dan 'Utsaymin; informan Ahmadiyah pada Mirza Ghulan Ahmad dan para khalifah Ahmadiyah; demikian pula informan

16Lihat Qs. al-Baqarah (2): 148. Selain itu, ayat-ayat lain yang kerap mereka kutip untuk melegitimasi pandangan mereka tentang keragaman sebagai sunnatullăh, misalnya Qs. al-Mā'idah (5): 48; Qs. Hūd (11): 118; Qs. al-Nahl (16): 93; dan Q.s. Yūnus [10]: 99. 
Jamaah Tabligh kerap menyitir pandangan keagamaan sang pendiri, Syaikh Maulana Muhammad Ilyas.

Para informan memang bersepakat bahwa keragaman itu sunnatullāh. Namun, mereka berbeda soal perlu-tidaknya keragaman itu diseragamkan. Sebagian bilang bahwa penyeragaman perlu agar umat Islam kembali "satu" seperti di zaman Rasul saw dan yakin bahwa cita "umat yang seragam dalam keyakinan" mungkin untuk dicapai. Sebagian lagi meyakini kemungkinan itu kendati mustahil mencapai 100\% "seragam", tetapi itu bukan alasan untuk meniadakan ambisi penyeragaman. Hanya (informan) Syi'ah yang menegaskan, penyeragaman keyakinan itu mustahil sehingga tidak perlu dilakukan.

Dengan pandangan masing-masing, para informan memaknai sekaligus menyikapi kelompok keagamaan lain (the others). Bagi yang pro-penyeragaman, mereka saling menilai dan memandang keyakinan the others salah dan karena itu perlu diseragamkan dengan menjadikan keyakinan diri sebagai tolok ukur kebenaran. Bagi yang tidak, semisal kelompok Ahmadiyah, cenderung menahan diri dalam menilai seraya menganggap hanya Allah yang tahu pasti sesattidaknya keyakinan suatu kelompok.

Seluruh pandangan tersebut menjadi titik tolak informan dalam melakukan adaptasi sosial, yakni adaptasi diri di tengah realitas sosial yang heterogen. Inilah momen di mana mereka sebagai individu mengadaptasikan diri dengan lingkungan sosialnya berupa penolakan atau penerimaan atau kompromi terhadap anasir keyakinan lain. Bentuk-bentuk adaptasinya mengejawantah lewat tindakan dan verbalisasi pemikiran yang dari keduanya mereka mencipta realitas. Dalam hal ini bahasa dan tindakan merupakan sarana dalam mencipta. Itu sebabnya mereka kompak memaknai aktivitas dakwah sebagai upaya mengkonversi orang dari keyakinan lamanya yang "sesat dan menyimpang" ke keyakinan diri yang "benar dan lurus". Hanya sebagian kecil yang tidak berorientasi sedemikian meski merasa senang jika ada jamaah kelompok lain "pindah keyakinan" ke kelompoksendiri.

Semua informan beranggapan bahwa pluralitas keyakinan di intern umat Islam bukanlah ancaman bagi keberhasilan dakwah, tetapi justru peluang untuk melangsungkan dakwah yang bersemangat raḥmatan li al-'alaminn. Pemaknaan senada juga dikhidmati oleh semua informan, tentu dengan orientasi dakwah berbeda. Bagi sebagian besar informan, pluralitas itu justru alasan untuk kian bersemangat menjalankan dakwah, yakni mengajak umat sebanyak-banyaknya 
ke "jalan yang benar", yakni jalan keyakinan yang dikonstruksi kelompok sendiri.

Bagaimana jika setelah didakwahi secara persuasif, kelompok yang berkeyakinan "sesat" itu masih tetap saja ngeyel, bersekukuh dengan keyakinannya, dan bahkan balik menyalahkan keyakinan pendakwah? Semua informan kompak menilai, dakwah pada dasarnya adalah proses tanpa finalitas; jika suatu kelompok tetap ngotot bertahan pada keyakinan "sesat"-nya justru harus dijadikan alasan untuk terus berdakwah. Bagi mereka, model dakwah terbaik di tengah pluralitas keyakinan adalah dakwah persuasif berspirit "mengajak" pada kebenaran sebagaimana diajarkan Allah (QS. al-Naḥl [16]: 125). Namun, uniknya, sebagian informan tetap menekankan perlunya membatasi ruang gerak, bahkan melarang, kelompok lain yang dinilai "sesat" untuk beraktivitas keagamaan. Dalam hal ini, kelompok sasaran yang kerap dicontohkan harus dibatasi atau dilarang adalah Ahmadiyah dan Syi'ah.

Dengan demikian jelas bahwa adaptasi sosial mereka di ujung proses eksternalisasi berbeda-beda dan karena itu bentuk adaptasi diri mereka pun berbeda-beda pula di tengah lingkungan sosial Kota Mataram, mulai dari penerimaan, penolakan, hingga kompromi. Masing-masing bentuk adaptasi sosial itu berperan determinan sebagai pelempang jalan bagi keutuhan konstruksi sosial mereka di dua momen lainnya, yakni objektivasi dan internalisasi.

Dalam momen objektivasi, para elit kelompok keagamaan juga cenderung selalu melakukan penyesuaian bentuk-bentuk interaksi sosialnya dengan teksteks suci (al-Qur'an dan al-Hadis) sembari merujuk interpretasi atau konstruksi ulama mereka masing-masing. Bermodalkan itu, mereka melangsungkan interaksi sosial di tengah dinamika sosial-keagamaan Kota Mataram. Melalui proses interaksi sosial, momen objektivasi ini memuncukan jalinan intersubjektivitas. Dalam prosesnya, setiap informan melakukan interaksi diri dengan dunia sosial-kulturalnya yang kemudian membentuk jalinan interaksi yang intersubjektif. Jalinan inilah yang menyusun realitas objektif yang unik (sui generis) tentang dinamika keberagamaan terkait otherness di kota ini. ${ }^{17}$

Dalam studi ini, proses objektivasi dipahami sebagai proses pemberian makna baru terhadap realitas sosial menyangkut the others. Melalui interaksi

17Pemerian teoretiknya bersandar pada Berger dan Luckmann, Tafsir Sosial, h. 28-65. 
sosial, makna baru itu dikonstruksi dan lalu diobjektivasi sedemikian rupa oleh para informan di tengah situasi sosial-kultural kota yang heterogen dari sisi keyakinan keagamaan. Dalam konteks situasi itu, wujud interaksi yang berlangsung kadang bertendensi protagonistik kadang pula antagonistik.

Bentuk-bentuk interaksi sosial yang dihabitualisasi terus-menerus melalui tindakan berulang-ulang pada akhirnya semakin membuatnya terlembagakan di ruang sosial-kultural (cultural space) masyarakat dan diterima sebagai kebenaran objektif. Terlebih setiap interaksi sosial yang mereka lakukan senantiasa dilegitimasi oleh teks-teks suci dan pada saat yang sama juga merefleksikan konteks. Pemberian legitimasi dengan teks suci dan pengukuhan interpretasi dari para ulama kelompok masing-masing praktis menguatkan kesadaran bahwa segenap tindakan terkait merupan tindakan yang positif dalam memaknai keragaman dan menyikapi keyakinan religius kelompok lain.

Pada diri informan, proses objektivasi itu dapat dilihat pada tindakan mereka selaku elit dalam hubungan antarkelompok keagamaan, antara lain lewat aktivitas dakwah, dan pandangan mereka terhadap hubungan itu sendiri. Tidak seperti informan dari kelompok keagamaan mayoritas seperti NW dan Muhammadiyah, para informan dari kelompok keagamaan minoritas seperti Syi'ah dan Ahmadiyah praktis belum pernah berdakwah — dalam pengertian sempit, berceramah atau memberi pengajian - ke komunitas kelompok lain yang berbeda keyakinan; dakwah hanya mereka lakukan di intern kelompok sendiri.

Kendati mengaku belum pernah, para tokoh minoritas itu sangat berhasrat untuk berkesempatan melakukan dakwah ke tengah komunitas lain; mereka berharap pemerintah memfasilitasi. Hanya saja orientasi masing-masing informan berbeda. Ada yang berniat melakukannya dengan tujuan ingin mengkonversi suatu kelompok keyakinan ke keyakinan kelompoknya sendiri (Salafi). Ada pula yang ingin melakukannya hanya dalam format dialog, sekedar utuk mengklarifikasi aneka tuduhan dan kesalahpahaman yang selama ini dialamatkan ke mereka (Ahmadiyah, Syi'ah). Ada pula yang tidak memedulikan disparitas keyakinan selain sekedar mengajak untuk "menjalani hidup seperti Rasulullah" dengan menjadikan masjid sebagai pusat nadi kehidupan (Jamaah Tabligh).

Uniknya, walaupun berkeinginan dapat berdakwah ke kelompok lain, kelompok-kelompok minoritas secara umum bersikap "pasang kuda-kuda" bahkan keberatan terhadap inisiatif dakwah kelompok lain ke tengah mereka; 
hal yang sama persis dengan sikap kelompok Muslim mayoritas. Di ranah interaksi sosial, sikap demikian telah membentuk pola hubungan antarkelompok yang unik, serba kontradiktif, di mana keterbukaan dalam hubungan cenderung ambigu dan setengah hati. Hal itu menegaskan bahwa setiap kelompok secara naluriah berkepentingan untuk mempertahankan keyakinan diri sembari menganggapnya lebih benar; sementara terhadap keyakinan kelompok lain, selain disalahkan juga patut diwaspadai agar anggota kelompoknya tidak terkonversi ke keyakinan kelompok lain itu. Itu berarti mereka tidak ada bedanya dengan Ahmadiyah, sama-sama ngotot mempertahankan keyakinan. Bedanya, jika kelompok lain (terutama yang mayoritas), tidak suka "didakwahi" tetapi selalu ingin "mendakwahi", maka Ahmadiyah ingin "mendakwahi", tetapi tidak menolak untuk "didakwahi".

Menariknya, di tengah ambiguitas sikap itu, semua informan tetap memandang penting toleransi. Namun, sekali lagi, di level interaksi sosial, toleransi dimaknai secara berbeda oleh setiap informan sejalan dengan kepentingan masing-masing kelompok. Bagi kelompok minoritas seperti Syi'ah dan Ahmadiyah, toleransi bermakna penghormatan terhadap kelompok lain dalam memilih keyakinan sekaligus mengekspresikannya ke dalam aktivitas ritual maupun sosial di ruang privat maupun publik. Sementara, bagi kelompok mayoritas seperti NW, toleransi terhadap pilihan keyakinan diberikan sejauh keyakinan dimaksud tidak menodai keyakinan kelompok mayoritas.

Terkait pola ideal hubungan antarkelompok, semua informan menyebut bahwa interaksi terbaik antarkelompok keagamaan adalah dialog. Bagi kelompok minoritas seperti Ahmadiyah dan Syi'ah, dialog sangatlah penting, terutama untuk mengurai kesalahpahaman, menglarifikasi tuduhan, dan mencari titik persamaan antarkeyakinan agar tercipta kedamaian, koeksistensi, dan toleransi produktif antarkelompok. Sementara, bagi kelompok mayoritas, dialog juga diangap penting sejauh masing-masing pihak yang terlibat mau jujur terbuka dan bersedia melepas keyakinannya jika dalam dialog terbukti keyakinannya lebih lemah.

Seluruh proses objektivasi di atas menunjukkan bahwa interaksi sosial yang dibangun sebagai realitas objektif oleh para informan telah berkonsekuensi pada relasi hubungan antarkelompok keagamaan. Konsekuensi yang muncul kerap mendua, di satu saat kadang protagonistik dan di saat lain tak jarang antagonistik. 
Selanjutnya, serupa dengan momen eksternalisasi dan objektivasi, pada momen internalisasi penghayatan para informan bertitik anjak dari teks suci yang diperkuat dengan aneka konstruksi para ulama pendahulu kelompok masing-masing. Pada momen ini, mereka memaknai keragaman institusi keagamaan melalui proses identifikasi sosial, yakni identifikasi diri di tengah dinamika sosial. Pada proses ini konstruksi tentang the others menampak jelas dalam diri para informan, terinternalisasi. Jika momen eksternalisasi dan objektivasi membentuk realitas objektif tentang kehidupan antarkelompok keagamaan, maka momen internalisasi membentuk realitas subjektif yang dikontruksi dalam kesadaran keagamaan mereka. Kesadaran inilah yang membimbing mereka dalam melakukan adaptasi sosial lewat eksternalisasi dan interaksi sosial melalui objektivasi. ${ }^{18}$

Konstruksi mereka tentang the others bertemali erat dengan pluralitas keyakinan itu sendiri. Satu sisi pluralitas itu dianggap sunnatullāh, tetapi di sisi lain mereka diam-diam berhasrat untuk menyeragamkannya. Ini berkait rekat dengan konstruksi sosial mereka sendiri tentang the others yang bertumpu pada "merasa berbeda dengan yang lain". Perasaan tersebut berkait dengan keyakinan keislaman mereka sebagai tolok ukur membedakan diri dengan "yanglain". Hanya (informan) Jamaah Tabligh yang tidak merasa berbeda dengan kelompok lain, mungkin tepatnya tidak peduli dengan kemungkinan adanya perbedaan itu.

Berbeda dengan Jamaah Tabligh yang "merasa tidak berbeda" dengan kelompok keyakinan lain, para informan lain secara terus-terang mengaku merasa berbeda, tak terkecuali kelompok minoritas seperti Ahmadiyah dan Syi'ah. Pangkal dari perasaan "berbeda" itu ialah sistem keyakinan sendiri yang dipancang sebagai tolok ukur untuk menilai keyakinan kelompok lain, sama atau berbeda dan akhirnya benar/lurus atau salah/menyimpang.

Jika ditrasir, perbedaan itu terutama menyangkut apa yang disebut 'aqìdah (pokok keimanan) dan hal-hal furü'iyah (cabang, aspek luar keimanan, seperti tata cara peribadatan, dan sejenisnya). Kebanyakan informan tidak mempersoalkan wilayah furü'iyah yang dianggap partikular dan merupakan wilayah yang bisa diperdebatkan (majal al-ijtihād). Berbeda halnya dengan persoalan

18Peter L. Berger, Langit Suci, h. 32-5; juga Nur Syam, Islam Pesisir (Yogyakarta: LKíS, 2005), h. 37- 
'aqïdah yang, menurut mereka, sudah bersifat pasti (qațiy) dan karenanya tidak bisa lagi diperdebatkan. Klaim "sesat" umumnya dimainkan di area "pokok keimanan" ini. Namun, khusus Salafi, klaim itu juga dilekatkan pada hal-hal furūityah.

Dalam hal 'aqìdah, perbedaan diametral antarkeyakinan dirasakan semua kelompok keagamaan, terutama dalam hal kenabian, pewahyuan, dan ketuhanan. Dalam soal kenabian, misalnya, keyakinan kelompok Ahmadiyah yang memungkinkan ada nabi pasca-kenabian Muhammad berbeda diametral dengan semua kelompok yang justru meyakini sebaliknya bahwa mustahil ada nabi setelah kenabian Muhammad. Inilah yang menjadi alasan pokok bagi kelompok lain, terutama kelompok keislaman mayoritas, untuk menilai Ahmadiyah sebagai kelompok yang tidak hanya "berbeda", tetapi juga "sesat-menyesatkan" dan "berada di luar Islam". Juga soal pewahyuan, misalnya keyakinan Syi'ah yang disebut-sebut meyakini pewahyuan atas sayyidinā 'Alī ibn Abī Thalib dan Ahmadiyah yang mempercayai pewahyuan terhadap Mirza Ghulam Ahmad dianggap oleh kelompok lain bertentangan dengan keyakinan mereka yang justru menganggap proses pewahyuan sudah berakhir pascakewafatan Nabi. Begitu juga soal ketuhanan, khususnya masalah $a s m a$ ' dan sifat Allah, keyakinan Salafi dinilai berbeda oleh kelompok Islam mayoritas yang notabene menganut 'aqïdah Asy'ariyah; demikian pula sebaliknya.

Perasaan "berbeda" itu kemudian mengantarkan mereka pada pengunggulan diri masing-masing. Kecuali informan Jamaah Tabligh yang konsisten tidak merasa berbeda dan karena itu tidak menganggap keyakinan religiusnya lebih unggul dan lebih benar dari yang lain, semua informan menganggap bahwa formulasi keyakinan diri lebih benar dan unggul dari keyakinan kelompok lain. Kendati berbeda gaya ungkap, kelompok minoritas seperti Ahmadiyah, Syi'ah, dan Salafi juga beranggapan sedemikian. Mereka hanya berbeda di tingkat cara menyikapi perbedaan itu. Ada yang mengajukan cara dialog (Ahmadiyah dan Syi'ah), ada pula yang menekankan perlunya penyadaran lewat dakwah dengan motif penyeragaman (Salafi dan kelompok Muslim mayoritas, NW dan Muhammadiyah).

Mengunggulkan keyakinan religius diri, merasa keyakinan diri paling benar dan yang lain salah, inilah yang kemudian mendorong munculnya perasaan "bahagia" jika ada kelompok lain konversi ke keyakinan kelompok sendiri. Orang mungkin bilang ini tabiat naluriah setiap pemeluk keyakinan. Akan tetapi, 
bagi mereka, ini lebih merupakan pilihan sadar yang bertumpu pada kesadaran kausal bahwa keyakinan kelompok lain itu "salah" dan penganutnya harus "diselamatkan". Di titik ini kebahagiaan mereka menyambut tindakan "riddah" (apostasy) anggota kelompok lain ke kelompok sendiri menjadi bagian integral dari konstruksi sosial mereka tentang the others.

Tak pelak, melalui konstruksi sosial para informan, the others menjadi realitas subjektif. Apa yang mereka identifikasi sebagai the others diinternalisasi sebagai sesuatu "yang lain", yang berbeda dengan diri. Sesuatu yang berbeda dinilai berdasar tolok ukur keyakinan diri. Mereka yang tidak sama dengan keyakinan diri seketika dianggap berbeda. Sampai di sini mungkin tidak masalah, tetapi menjadi complicated ketika penilaian berbeda selalu berkonsekuensi pada klaim lanjutan bahwa yang berbeda itu "salah", "menyimpang", dan "sesatmenyesatkan", sementara keyakinan anutan diri benar, lurus, dan diridhai Allah. Perasaan inilah yang menuntun mereka pada klaim teologis sebagai kelompok yang paling selamat. Sementara, bagi the others, jika ingin selamat tidak ada cara lain kecuali menyamakan diri dengan keyakinan mereka, jika tidak maka berlakulah "hukum besi dakwah jalanan": insafkan, jika tidak mau, paksa!

Secara teoretik, konstruksi sosial informan tentang the others sedikitbanyak menguatkan tesis poskolonial bahwa pandangan akan otherness bertumpu pada anggapan egosentris yang memandang diri sendiri lebih unggul dan lebih benar dibanding the others.19 Melalui momen internalisasi, mereka membangun relasi kuasa berdasar (ideologi) pengetahuan keagamaan masingmasing dengan menempatkan pengetahuan keagamaan the others sebagai entitas yang harus ditundukkan. ${ }^{20}$ Ideologisasi pengetahuan keagamaan diri itu lalu diteguhkan ke dalam benak publik guna memperkuat relasi kuasa dengan menaklukkan seluruh ideologi pelawan, yakni ideologi keagamaan the others. Inilah yang melempangkan jalan bagi pengunggulan diri setiap kelompok di hadapan the others. Dengan pengunggulan diri, masing-masing kelompok mendaku keyakinan diri sebagai yang terbenar dibanding keyakinan the others. Tidak ada pilihan yang tersedia bagi the others kecuali menyesuaikan dengan konstruksi keyakinan diri atau jika tidak dengan segera dilekati stigma sebagai "salah" dan "sesat".

19Paranjape, “The Third Eye," h. 55-67.

${ }^{20}$ Landry dan MacLean (eds.), The Spivak Reader, h. 141-74. 
Dalam ruang sosial-kultural keagamaan yang heterogen, model identifikasi sosial para informan yang menempatkan diri "lebih unggul" dari the others tentulah bertumpu pada dan digerakkan oleh apa yang disebut Berger sebagai pragmatic motives. ${ }^{21}$ Pada diri informan, motif pragmatis ini terpilah pada dua faktor, eksternal dan internal. Pada faktor eksternal, motif pragmatis berupa: (1) keuntungan secara politis, yakni peluang untuk "mendominasi" di tengah pluralitas; (2) pengakuan sosial akan eksistensi diri, baik selaku elit/individu maupun kelompok; dan (3) upaya memperkuat soliditas kelompok di hadapan the others. Sementara, pada faktor internal, motif pragmatis berupa: (1) peneguhan privilege sosial sekaligus legitimasi diri sebagai elit kelompok; dan (2) ketenteraman batin terkait perolehan pahala lantaran "jihad"-nya dalam memperjuangkan keyakinan yang "benar".

Mengingat kapasitas para informan selaku elit di kelompok masing-masing, tentu menarik membayangkan apa kira-kira implikasi konstruksi sosial mereka tentang the others bagi mentalitas keagamaan umat di tengah heterogenitas kelompok keyakinan di Kota Mataram. Untuk meraba implikasinya, studi ini menerapkan tipefikasi terhadap kontruksi sosial mereka. Mengetahui tipologi mereka bakal memudahkan pemindaian implikasi itu sekaligus pengajuan solusi ideal bagi penciptaan koeksistensi antarkelompok keagamaan yang berbasiskan konstruksi sosial mereka sendiri tentang the others di kota ini.

\section{Tipologi}

Proses tipefikasi terhadap konstruksi sosial para elit dilakukan dengan mengenakan tiga model keberagamaan sebagai kerangka tipologi, ${ }^{22}$ yakni eksklusivisme, ${ }^{23}$ inklusivisme, ${ }^{24}$ dan pluralisme. ${ }^{25}$ Terdapat tiga karakteristik utama yang menyusun eksklusivisme sebagai suatu paradigma keberagamaan. ${ }^{26}$

21Berger dan Luckmann, Tafsir Sosial..., 28-65.

22Pemerian ketiganya merujuk Raimundo Panikkar, Dialog Intrareligius, terj. J. Dwi Helly Purnomo dan P. Puspobinatmo (Jogjakarta: Kanisius, 1994), h. 18-24; dan Terrence W. Tilley, Postmodern Theologies and Religious Diversity (Maryknoll, New York: Orbis Book, 1996), h. 158.

${ }^{23}$ Ide dasar eksklusivisme bertumpu pada formula "salvation is found in only one religion". Lihat Michael J. Vlach, "What are Pluralism, Inclusivism, and Exclusivism?", dalam http://www. theologicalstudies.org/pluralism.html. (23 Desember 2015).

${ }^{24}$ Formulasinya: "one religion is best but salvation is possible in other religions". Ibid.

${ }^{25}$ Frase ringkasnya, "all major world religions lead to God and salvation". Ibid.

${ }^{26}$ Sebenarnya ada empat karakteristik sebagaimana diteoretisasi Fatimah Husein, MuslimChristian Relations in the New Order Indonesia: The Exclusivist and Inclusivist Muslims' Perspectives 
Pertama, meyakini bahwa kebenaran (truth) dan keselamatan (salvation) hanya terdapat pada keyakinan anutan sehingga hanya keyakinan dan kelompoknya sendiri yang dianggap benar dan terselamatkan, sementara keyakinan kelompok lain salah dan celaka. Tendensi ini menampak terutama pada bagaimana para informan, dalam hal ini tokoh Salafi, Muslim tradisionalis (NW), Muslim modernis (Muhammadiyah), meneguhkan sikap zero tolerance dalam menyikapi ajaranajaran nyeleneh, khususnya menyangkut soal 'aqïdah seperti konsep messianisme Ahmadiyah. Bagi mereka, formulasi keagamaan Ahmadiyah tersebut bukanlah produk penafsiran, melainkan sungguh-sungguh tindak penodaan terhadap Islam.

Sejalan dengan spirit teologisnya yang tidak menenggang kebenaran "yang lain", paradigma eksklusif jelas tidak merekomendasikan dialog. Namun, dalam perspektif informan, urgensi dialog tetap diakui. Dalam hal inilah tendensi inklusivisme samar-samar mencuat dalam konstruksi sosial mereka. Hanya saja, dialog mereka maknai sebatas dialog antarkeyakinan keagamaan yang masih dalam koridor keislaman "yang benar", sedangkan terhadap kelompok yang sudah terhukum "sesat", dialog dipandang sudah tak lagi perlu; pandangan ini dipegangi terutama oleh para informan kelompok Muslim mayoritas. Tak ayal, kebanyakan forum dialog seperti yang difasilitasi MUI Kota Mataram dan NTB bukanlah dialog sejati, melainkan ajang pengadilan dan ujungnya adalah "memaksa" para penganut keyakinan "sesat" untuk al-rujū' ilā al-ḥaqq; inilah yang dirasakan kelompok Muslim minoritas sebagaimana diungkap informan Ahmadiyah dan Syi'ah.

Kedua, model keberagamaan eksklusif secara paradigmatik cenderung menerapkan pendekatan literal (literal approach) dalam memahami ajaran. Kecenderungan metodis tersebut tertangkap sama-samar beroperasi dalam pemikiran sebagian besar informan. Mereka memang tidak secara total menampilkan kecenderungan demikian. Justru dalam banyak isu keagamaan mereka cenderung kontekstual. Akan tetapi, ketika menyangkut isu yang dianggap terkait 'aqïdah seketika itu pula mereka berlaku tekstual seraya menutup kemungkinan varian penafsiran di luar konstruksi teologis mereka. Kecenderungan ini diidap informan NW, Salafi, Syi'ah, dan juga Muhammadiyah.

Karakteristik ketiga dari eksklusivisme adalah kepercayaan berlebih terhadap teori konspirasi. Sebagian besar informan, terutama dari Salafi, NW, dan

(Bandung: Mizan, 2005), h. 29-30. Namun, terkait konteks dan fokus penelitian, di sini hanya menunjuk tiga.

JURNAL THEOLOGIA — Volume 27, Nomor 2, Desember 2016 
Jamaah Tabligh, diam-diam menyimpan kepercayaan serupa. Terhadap kemunculan kelompok-kelompok berkeyakinan "nyeleneh", misalnya, mereka menduga keterlibatan konspiratif Barat atau non-Muslim (Yahudi dan Nashrani) untuk memecah-belah Islam. Kelompok yang paling kerap dituding merupakan buah dari proyek konspirasional Barat adalah Syi'ah dan Ahmadiyah. Syi'ah dituding buah dari kerja strategis Yahudi dan Ahmadiyah dianggap bikinan Barat (Inggris) yang dimaksudkan untuk memorak-porandakan Islam. Layaknya tuduhan berbasis teori konspirasi, mereka tidak memiliki bukti faktual untuk melegitimasi tengara itu, kecuali dalih normatif seperti QS. al-Baqarah [2]: 120.

Dalam pada itu tendensi inklusivisme dapat pula dijumpai lamat-lamat dalam konstruksi sosial para informan. Kriteria dari model keberagamaan inklusivisme sendiri secara umum menunjuk pada tiga karakteristik utama. ${ }^{27}$ Pertama, tetap meyakini bahwa agama anutan adalah agama terbenar. Namun, keyakinan itu tidak meniadakan empati bahwa kebenaran mungkin juga dimiliki oleh keyakinan lain dan karena itu para pengayuh paradigma ini cenderung toleran terhadap perbedaan; setiap agama diyakini memiliki kebenarannya sendiri-sendiri. Basis teologi inklusif ini cenderung ditolak oleh kebanyakan informan, kecuali Ahmadiyah. Bagi mereka, itu meniadakan batas antara yang haqq (benar) dan yang bāțil (salah); seolah semua agama atau keyakinan sama-sama diridlai Allah, padahal hanya Islam-lah yang diakui-Nya atau hanya keyakinan versi kelompok sendiri-lah yang diridhai-Nya.

Adapun karakteristik kedua dari inklusivisme adalah cenderung menggunakan pendekatan yang secara paradigmatik kontekstual (contextual approach) dalam memahami ajaran agama. Karakteristik ini dalam batas-batas tertentu juga dihela oleh informan, kecuali dalam hal-hal prinsip ('aqïdah). Kemudian, sejalan dengan tabiatnya yang cenderung apresiatif terhadap perbedaan, inklusivisme juga melengkapi diri dengan karakteristik ketiga, yakni cenderung tidak mempercayai teori konspirasi. Para penghayatnya dituntut saling berbaik sangka dalam relasi antarkeyakinan sehingga kehidupan damai di tengah kemajemukan mungkin dibangun. Ironisnya, tendensi ini relatif absen dalam logika keagamaan para informan.

Tipologi pemaknaan informan umumnya bermain di antara "dua kaki", kadang eksklusif, kadang inklusif. Tunjuk misal, pluralitas keyakinan di tubuh

${ }^{27}$ Ibid., h. 31. Ada empat karakteristik disebut Husein, tetapi studi ini memilih tiga di antaranya. 
umat Islam mereka maknai sebagai sunnatullāh, tetapi pada saat yang sama mereka berambisi menyeragamkan, menghabisi sunnatullāh itu. Pandangan pertama inklusif, tetapi ambisi itu membuat mereka seketika eksklusif. Mereka, misalnya, mempersilahkan Ahmadiyah atau Syi'ah bertahan dengan keyakinannya, tetapi di saat berbarengan mereka berlaku eksklusif dengan memprovokasi Negara untuk membatasi gerak, bahkan melarang aktivitas keduanya.

Fakta "inkonsistensi" itu mengkonfirmasi betapa mustahil melakukan pengelompokan tipologis secara clear cut atas konstruksi mereka. Di simpul-simpul tertentu selalu ada wilayah abu-abu (grey area) yang menyiratkan "inkonsistensi" paradigmatik itu. Namun, yang pasti, fakta itu menegaskan absennya paradigma ketiga, pluralisme, mengingat secara paradigmatik ia adalah level lanjut dari inklusivisme. Pluralisme tidak hanya menegaskan pemahaman positif tentang the others yang meyakini adanya perjumpaan substantif antarajaran, tetapi juga mengakui adanya disparitas masing-masing ajaran..$^{28}$

Sejauh menyimak seluruh pemikiran informan tentang the others, tendensi pluralisme sama sekali tidak terjumpai di dalamnya. Ketiadaan itu dapat disisir terutama dari pandangan mereka tentang pluralisme agama itu sendiri. Mereka umumnya menolak. Bagi mereka, mustahil membawa ide pluralisme ke wilayah agama karena setiap agama mengusung ide teologis dan bagan ajaran yang saling berbeda bahkan berlawanan. Bagi sebagian informan, ia hanya mungkin diwujudkan di ranah sosial. Memaksakannya ke wilayah agama justru bakal merusak integritas agama; agama akan mengalami desakralisasi. Dalam hal ini hanya informan Ahmadiyah yang menilai penting penguatan pluralisme di tengah pluralitas keyakinan, tetapi ia inkonsisten ketika diam-diam berhasrat mengkonversi kelompok lain ke Ahmadiyah dan merasa bahagia bila itu berhasil.

Demikianlah, berdasar kerangka pembacaan tiga tipologi, semua pemaknaan informan atas the others cenderung eksklusif dan dalam batas-batas tertentu juga inklusif, sementara tendensi pluralistik praktis tidak terjumpai. Tendensi eksklusivisme memang dominan. Hanya dalam batas-batas tertentu anasir inklusivisme muncul beririsan dan itu pun cenderung fragmentaris sehingga tidak memadai untuk menyebut konstruksi mereka bertipe inklusif. Kuatnya tendensi eksklusif otomatis membuat anasir pluralisme absen.

\footnotetext{
h. 6 .

${ }^{28}$ Gamal al-Banna, Doktrin Pluralisme dalam al-Quran, terj. Taufik Damas (Jakarta: Menara, 2006),
} 
Simpulan ini bersandar pada fakta terpenuhinya sebagian besar kriteria eksklusivisme dalam konstruksi sosial mereka daripada kriteria inklusivisme dan apalagi pluralisme.

\section{Mengelola Keragaman}

Fakta pluralitas keagamaan di satu sisi dan konstruksi sosial para elit kelompok keagamaan tentang the others yang cenderung eksklusif di sisi lain memang potensial mengeskalasi konflik jika tidak terkelola baik. Namun, jika dikelola dengan baik, dua hal tersebut justru berpotensi produktif bagi penguatan kohesivitas sosial dan penataan kehidupan keagamaan yang damai, harmonis, dan toleran di Kota Mataram.

Dalam kerangka pengelolaan keragaman berbasis konstruksi sosial para elit kelompok keagamaan, terdapat sejumlah hal solutif yang mendesak diupayakan agar dinamika kehidupan keagamaan di Kota Mataram berlangsung produktif bagi koeksistensi antarkelompok. Pertama, revitalisasi tradisi dialog antarkelompok keagamaan. ${ }^{29}$ Melalui dialog intensif, jejaring kerja sama dapat dikembangkan sebagai aksi bersama membangun koeksistensi dan toleransi. Soliditas jejaring dapat diarahkan untuk menyelesaikan aneka problem sosial seperti kemiskinan, kebodohan, ancaman konflik, dan juga kerusakan ekologis; tidak hanya mencari titik temu teologis. Dengan begitu, keragaman yang merupakan sunnatullāh dapat dimanfaatkan sebagai "energi sosial" guna memecahkan problematika umat.

Kedua, reorientasi aktivitas dakwah yang rule of game-nya disusun bersama oleh semua kelompok. Aktivitas dakwah setiap kelompok harus dibatasi areanya hanya di lingkup kelompok sendiri. Spiritnya direorientasi pada membina umat (sendiri) dan bukan memperbanyak umat. Ini penting karena setiap kelompok — sebagaimana terefleksi dari konstruksi sosial informanbernafsu ingin berdakwah di kelompok lain, tetapi menolak didakwahi oleh kelompok lain. Pada saat yang sama reorientasi dakwah diarahkan pada penguatan kesadaran toleran dan empatik terhadap keragaman seraya menghindari cara-cara kekerasan..$^{30}$

${ }^{29}$ Revitalisasi seyogyanya dilakukan di luar yang telah diinstitusionalisasi MUI dan FKUB; keduanya selama ini justru menjadi part of problem karena dialog yang dilangsungkan acap bias mayoritas dan hanya menjadi rutinitas atau sekedar langkah reaktif setiap kali ada konflik.

${ }^{30}$ Inspirasi dipungut dari penegasan QS. al-Māidah [5]: 8. 
Ketiga, reedukasi. Titik tekannya ialah meredesain seluruh sistem pendidikan, mulai hakikat ontologisnya, nilai-nilai, paradigma, epistemologi, hingga strategi dan metodologinya dengan inklusivisme dan/atau pluralisme sebagai basis. ${ }^{31}$ Proses reedukasi dapat dimulai di lembaga-lembaga pendidikan yang dikelola kelompok masing-masing, sedangkan pemerintah memiliki obligasi moral untuk memfasilitasinya dengan memperluas aksesibilitas pendidikan.

Keempat, reorientasi peran MUI. Dalam hal ini MUI harus menjadi rumah bersama bagi semua ulama dari berbagai latar keyakinan, dari kelompok mayoritas maupun minoritas. Kelompok-kelompok minoritas harus juga memiliki representasi secara institusional di MUI. Tanpa itu, semua tindakan MUI, misalnya lewat fatwa, akan terus bias-mayoritas dan kelompok minoritas pun bakal terus terkorbankan secara teologis dan bahkan sosial-politis.

Terakhir, kelima, penegakan hukum. Hal ini sering terabaikan, padahal berperan krusial sebagai langkah kuratif atas setiap konflik atau kasus kekerasan bertendensi agama. Dalam kerangka itu negara harus berlaku sebagai institusi yang adil dalam memediasi-meregulasi lalu-lintas kepentingan masyarakat, termasuk kepentingan keagamaan, berdasar prinsip-prinsip konstitusionalisme. $^{32}$

Demikianlah lima hal yang dapat diformulasikan berdasar konstruksi sosial informan seputar the others. Kelimanya memang tidak secara praktis menawarkan suatu model tertentu pengelolaaan keragaman. Namun, kelimanya dapat dijadikan kerangka awal menyusun suatu model yang sungguh-sungguh berbasiskan konstruksi sosial mereka; suatu model yang berspirit utama melindungi hak setiap kelompok untuk bebas menjalankan anutan keyakinan religius masing-masing sembari menjamin kelompok lain bebas pula berlaku serupa. Dalam perspektif pluralisme agama, penguatan spirit itu akan menuntun setiap kelompok, mayoritas maupun minoritas, pada kearifan dalam menyikapi perbedaan.

${ }^{31}$ Dalam hal redesigning pendidikan, tawaran Hernández tentang pendidikan multikuktural menarik ditimbang. Lihat Hilda Hernández, Multicultural Education: A Teacher's Guide to Linking Context, Process, and Content (New Jersey: Merril Prentice-Hall, 2001), h. 3-25; juga Donna M. Gollnick dan Philip C. Chinn, Multicutural Education in a Pluralistic Society (New Jersey: Merrill Prentice Hall, 2002), h. 196-235.

32Muhammad AS Hikam, Demokrasi dan Civil Society (Jakarta: LP3ES, 1996), h. 131-149. 


\section{Kesimpulan}

Akhirnya dapat disimpulkan bahwa konstruksi sosial para elit kelompokkelompok keagamaan di Kota Mataram tentang the others muncul lewat tiga momen dialektik, yakni eksternalisasi, objektivasi, dan internalisasi. Tipefikasi terhadap konstruksi sosial mereka menunjukkan dominannya tendensi eksklusif, samarnya hasrat inklusif mengemuka, dan absennya tendensi pluralistik.

Dalam kerangka pengelolaan keragaman berbasis konstruksi sosial para elit kelompok keagamaan tentang the others, lima hal berikut patut disegerakan, yakni: (1) revitalisasi tradisi dialog antarkelompok keagamaan; (2) reorientasi aktivitas dakwah yang rule of game-nya disusun bersama oleh semua kelompok; (3) reedukasi dengan orientasi pada penguatan toleransi; (4) reorientasi peran MUI; dan (5) penegakan hukum. Diharapkan melalui kelima hal tersebut dinamika kehidupan keagamaan yang begitu plural di Kota Mataram bersumbagsih produktif bagi koeksistensi antarkelompok. []

\section{DAFTAR PUSTAKA}

Ali-Fauzi, Ihsan, Rudy Harisyah Alam, dan Samsu Rizal Panggabean, "Pola-pola Konflik Keagamaan di Indonesia (1990-2008)", Laporan Penelitian, Jakarta: Paramadina-MPRK UGM-The Asia Foundation, 2009.

Asnawi, "Konflik dan Karakteristiknya," Makalah (tidak diterbitkan), Mataram: Mediation Centre IAIN Mataram, 2004.

Aziz, Ahmad Amir, dkk. "Tragedi 171 Mataram: Wujud Ketidakberesan Hubungan Antarumat Beragama?", Jurnal Ulumuna STAIN Mataram Vol. VIII Edisi 14 No. 2 (Juli-Desember, 2004): 300-17.

al-Banna, Gamal, Doktrin Pluralisme dalam al-Quran, terj. Taufik Damas, Jakarta: Menara, 2006.

Berger, Peter L., Langit Suci: Agama sebagai Realitas Sosial, terj. Hartono, Jakarta: LP3ES, 1991. dan Thomas Luckmann, Tafsir Sosial atas Kenyataan: Risalah tentang Sosiologi Pengetahuan, Jakarta: LP3ES, 1991.

Burhanudin, Jajat dan Arief Subhan, eds., Sistem Siaga Dini terhadap Kerusuhan Sosial, Jakarta: Balitbang Agama Depag RI dan PPIM, 2000. 
Dorrien, Gary. "Berger: Theology and Sociology", dalam Peter Berger and the Study of Religion, ed. Linda Woodhead, et.al., London: Routledge, 2001.

Geertz, Clifford. "The Javanese Kijaji: The Changing Role of a Cultural Broker," dalam Comparative Studies on Society and History, II/2, January, 1960.

Gollnick, Donna M. dan Philip C. Chinn, Multicutural Education in a Pluralistic Society, New Jersey: Merrill Prentice Hall, 2002.

Hagopian, Mark N., Regimes, Movement, and Ideology, New York: Longman, 1978.

Hasani, Ismail, ed. Submissive to Mass Judgment: State's Justification in Prosecuting Freedom of Religion and Belief, Jakarta: SETARA Institute, 2007.

Hernández, Hilda, Multicultural Education: A Teacher's Guide to Linking Context, Process, and Content, New Jersey: Merril Prentice-Hall, 2001.

Hikam, Muhammad AS, Demokrasi dan Civil Society, Jakarta: LP3ES, 1996.

Horrell, David G., "Berger and New Testament Studies", dalam Peter Berger and the Study of Religion, ed. Linda Woodhead, et.al., London: Routledge, 2001.

Huntington, Samuel P., "The Clash of Civilization?" dalam Foreign Affairs. Summer, 1993.

Husein, Fatimah, Muslim-Christian Relations in the New Order Indonesia: The Exclusivist and Inclusivist Muslims' Perspectives, Bandung: Mizan, 2005.

Landry, Donna dan Gerald MacLean (eds.), The Spivak Reader: Selected Works of Gayatri Chakravorty Spivak, New York: Routledge, 1996.

Panikkar, Raimundo, Dialog Intrareligius, terj. J. Dwi Helly Purnomo dan P. Puspobinatmo, Jogjakarta: Kanisius, 1994.

Paranjape, Makarand, "The Third Eye and Two Ways of (Un)knowing: Gnosis, Alternative Modernities, and Postcolonial Futures", dalam Postcolonial Philosophy of Religion, eds. Andrew B. Irvine and Purushottama Bilimoria. T.t.: Springer, 2009.

Roe, Hiroko Horikoshi, Kyai dan Perubahan Sosial, terj. Umar Basalim dan Andy Muarly Sunrawa, Jakarta: P3M, 1987.

Sai, M., dkk., "Gerakan Dakwah Salafiyah (Konflik Ideologis dan Sosial di Lombok Barat)," Laporan Penelitian, Mataram: Lemlit IAIN Mataram, 2007.

Syam, Nur, Islam Pesisir, Yogyakarta: LKíS, 2005.

Tilley, Terrence W., Postmodern Theologies and Religious Diversity, Maryknoll, New York: Orbis Book, 1996. 
Umam, Fawaizul, "Menolak Kekerasan, Menenggang Keragaman: Refleksi atas Kasus Kekerasan terhadap Ahmadiyah", Jurnal Tasāmuḥ FD IAIN Mataram Vol. 4 No. 1, Desember, 2006.

Vlach, Michael J., "What are Pluralism, Inclusivism, and Exclusivism?", dalam http://www.theologicalstudies.org/pluralism.html.

"Lampu Merah Kebebasan Beragama: Laporan Kebebasan Beragama dan Toleransi di Indonesia The WAHID Institute 2011", dalam http://www. wahidinstitute.org/Dokumen/Detail/?id=184/hl=id/Laporan_

Kebebasan_Beragama_2011_The_Wahid_Institute 